\title{
VALIDASI METODE MATRIX SOLID PHASE DISPERSION (MSPD)- SPEKTROFOTOMETRI UV UNTUK ANALISIS RESIDU TETRASIKLIN DALAM DAGING AYAM PEDAGING
}

\author{
Nofita, Rinawati, H.I. Qudus \\ Pasca Sarjana Kimia Fakultas Matematika dan Imu Pengetahuan Alam \\ Universitas Lampung \\ Email : pipit_nft@yahoo.com
}

\begin{abstract}
Method Validation Matrix Solid Phase Dispersion (MSPD)-Spektrofotometri UV for The Analysis of Residual Tetracycline in Meat Broilers. Tetracyline are antibiotics that have been widely used by poultryman to prevent diseases in dairy broiler chicken. Overuse of these antibiotics may lead to the presence of its residues in animal products including meat. Clinical implication that may occur such as allergy, intoxication, and spesific of antibiotic resistance. Tetracyclines residue in broiler chicken meat can be analyzed with ultraviolet spectrophotometer using standard addition technique. The meat was extracted with Matrix Solid Phase Dispersion (MSPD) method. Recovery was $84.40 \%$ according to standard addition method with acceptable limit $80-110 \%$. Relative standar deviation were $1.36 \%$. The limit of detection were $5.16 \mu \mathrm{g} / \mathrm{ml}$ and limit of quantitation were $5.54 \mu \mathrm{g} / \mathrm{ml}$. The linearity test presented a correlation coefficient were 0.9997 . The analysis of broiler chicken meat from three department store in Bandar Lampung city showed the amount of tetracyclines residue were $42.40 \mathrm{mg} / \mathrm{kg} ; 61.05$ $\mathrm{mg} / \mathrm{kg}$; and $44.47 \mathrm{mg} / \mathrm{kg}$. These value has exceeded the maximum limit of tetracycline residues in meat according to SNI 01-6066-2000, ie $0.1 \mathrm{mg} / \mathrm{kg}$.
\end{abstract}

Keywords: Tetracyclines, Broiler chicken meat, MSPD, Ultraviolet Spectrophotometry

\begin{abstract}
Abstrak: Validasi Metode Matrix Solid Phase Dispersion (MSPD) Spektrofotometri UV untuk Analisis Residu Tetrasiklin dalam Daging Ayam Pedaging. Tetrasiklin merupakan antibiotik yang umum digunakan sebagai obat-obatan veteriner untuk pencegahan penyakit. Penggunaan yang berlebihan dapat meninggalkan residu dalam produk peternakan tersebut, termasuk daging ayam. Implikasi klinis yang dapat terjadi, antara lain alergi, keracunan, dan resistensi. Residu tetrasiklin dalam daging ayam pedaging dapat dianalisis menggunakan spektrofometer ultraviolet dengan teknik adisi standar. Daging ayam diekstraksi lebih dulu menggunakan metode Matrix Solid Phase Dispersion (MSPD). Hasil uji perolehan kembali berdasarkan metode penambahan standar sebesar $84,40 \%$ dengan batas keberterimaan sebesar 80 $110 \%$. Penyimpangan baku relatif yang diperoleh $1,36 \%$; batas deteksi dengan konsentrasi 5,16 $\mu \mathrm{g} / \mathrm{ml}$; batas kuantitasi 5,54 $\mu \mathrm{g} / \mathrm{ml}$; dan linieritas dengan nilai koefisien korelasi 0,9997. Hasil uji analisis sampel daging ayam pedaging yang berasal dari tiga pusat perbelanjaan di kota Bandar Lampung menunjukkan bahwa kadar residu tetrasiklin $42,40 \mathrm{mg} / \mathrm{kg} ; 61,05 \mathrm{mg} / \mathrm{kg}$; dan 44,47 $\mathrm{mg} / \mathrm{kg}$. Nilai tersebut telah melebihi batas maksimum residu tetrasiklin dalam daging menurut SNI 01-6066-2000, yaitu $0,1 \mathrm{mg} / \mathrm{kg}$.
\end{abstract}

Kata kunci: Tetrasiklin, Daging Ayam Pedaging, MSPD, Spektrofotometer Ultraviolet

Antibiotika secara luas digunakan dalam dunia peternakan, baik untuk pengobatan, pencegahan penyakit, maupun sebagai tambahan dalam pakan yang mendorong pertumbuhan pada ternak. Hampir semua pabrik pakan menambahkan antibiotik ke dalam ransum jadi (Bahri dkk., 2000).

Penggunaan pakan yang kurang memperhatikan aturan pemberiannya atau penggunaan antibiotik sebagai pengobatan yang tidak sesuai dengan petunjuk, misalnya waktu henti obat tidak dipatuhi menjelang hewan akan dipotong, akan menyebabkan obat tertinggal di dalam jaringan/organ tubuh, disebut sebagai residu, yang kemudian akan terakumulasi dengan konsentrasi yang bervariasi. Kandungan residu antibiotik yang melewati batas maksimum residu (BMR) yang ditetapkan dapat menyebabkan reaksi alergi, resistensi, dan mungkin keracunan sehingga berbahaya bagi kesehatan manusia (Yuningsih, 2004).

Antibiotika tetrasiklin merupakan salah satu golongan antibiotika yang sering digunakan untuk pengobatan penyakit infeksi respirasi 
kronis yang disebabkan oleh Mycoplasma galliseticum, sinovitis yang disebabkan oleh Mycoplasma sinovae dan kolera unggas (fowl cholera) pada ayam (Cherlet et al., 2003). Adapun waktu henti pemakaian antibiotik golongan tetrasiklin adalah lima (5) hari menjelang ternak dipotong (Lastari dkk., 1987). Badan Standarisasi Nasional (BSN, 2000) menetapkan BMR yang tercantum dalam SNI 016366-2000 menetapkan bahwa batas cemaran residu tetrasiklin yaitu $0,1 \mathrm{mg} / \mathrm{kg}$ pada daging.

Residu antibiotik tetrasiklin dalam bahan pangan jumlahnya sangat kecil sehingga diperlukan suatu metode analisis yang baik dan teliti. Pengembangan metode dilakukan untuk mendapatkan nilai perolehan kembali yang lebih baik, serta metode deteksi yang lebih cepat dan teliti. Analisis residu antibiotik tetrasiklin secara Kromatografi Cair Kinerja Tinggi (KCKT) telah dikembangkan oleh Muriurki et al. (2001) dan Suryani (2009). Christina (2011) dengan metode yang berbeda melakukan penetapan kadar residu tetrasiklin dalam daging ayam pedaging secara adisi standar dengan spektrofotometri ultraviolet.

Dispersi matriks fase padat atau Matrix Solid Phase Dispersion (MSPD) merupakan aplikasi sebagai proses analisis untuk persiapan, ekstraksi, dan fraksinasi sampel biologis padat, semi-padat, atau sampel dengan kekentalan yang tinggi. MSPD didasarkan pada pencampuran mekanis untuk menghasilkan gangguan sampel lengkap dan interaksi matriks sampel dengan padatan pendukung yang terikat pada permukaan sampel. Aplikasi MSPD telah banyak dilakukan untuk analisis makanan (Barker, 2000), juga pernah digunakan untuk analisis residu tetrasiklin dalam daging sapi, susu, dan keju dengan menggunakan KCKT sebagai instrumentasi penetapan kuantitatif (Brandsteterova et al., 1997).

Dilihat dari struktur tetrasiklin yang mempunyai gugus kromofor (ikatan rangkap terkonjugasi) dan gugus auksokrom (gugus hidroksil, amida, dan amina), maka senyawa ini dapat menyerap radiasi pada panjang gelombang di daerah ultraviolet. Menurut Moffat (2004) tetrasiklin memiliki serapan maksimum dalam larutan asam pada panjang gelombang $270 \mathrm{~nm}$ dan $356 \mathrm{~nm}$. Metode ini juga mempunyai banyak keuntungan antara lain dapat digunakan untuk analisis suatu zat dalam jumlah kecil, pengerjaannya mudah, sederhana, cukup sensitif dan selektif, biayanya relatif murah dan mempunyai kepekaan analisis cukup tinggi (Munson, 1991).

Tujuan penelitian ini adalah untuk mengetahui apakah penetapan kadar residu pada daging ayam pedaging dengan menggunakan spektrofotometri ultraviolet secara adisi standar yang memanfaatkan teknik ekstraksi MSPD untuk preparasi sampel memenuhi uji validasi metode. Parameter validasi yang dilakukan meliputi akurasi, presisi, batas deteksi, batas kuantitasi, dan linieritas. Metode ini kemudian dapat dimanfaatkan sebagai monitoring kadar residu tetrasiklin dalam daging ayam pedaging yang sebaiknya rutin dilakukan untuk memastikan keamanan pangan.

\section{METODE PENELITIAN}

Metode penelitian yang dilakukan adalah penelitian eksperimental yang mengarah pada pengembangan metode. Tujuannya mengembangkan spektrofotometri ultraviolet secara adisi standar menggunakan tehnik ekstraksi MSPD dalam penetapan residu tetrasiklin dalam daging ayam pedaging. Penelitian ini dilaksanakan pada bulan Mei sampai dengan Oktober 2015 di Laboratorium Kimia Medik Universitas Malahayati.

Sampel yang diperiksa dalam penelitian ini adalah daging ayam pedaging bagian paha yang dijual di tiga pusat perbelanjaan di Kota Bandar Lampung, yaitu Hypermart (Central Plaza), Chandra (Chandra Supermarket \& Department Store Tanjung Karang), dan Giant (Giant Antasari) yang kemudian disebut sampel A, B, dan C. Sampel yang diambil dalam kondisi segar (bukan daging beku atau yang sudah diolah) kemudian dibersihkan (dibuang kulit dan tulang) dan disimpan dalam lemari pendingin. Sebelum digunakan untuk pemeriksaan, sampel terlebih dahulu dihaluskan dengan blender.

\section{Pembuatan Larutan Standar Tetrasiklin HCI BPFI}

Sejumlah lebih kurang 25,0 mg tetrasiklin hidroklorida $(\mathrm{HCl})$ BPFI ditimbang seksama, dimasukkan ke dalam labu ukur $50 \mathrm{ml}$, dilarutkan dengan $\mathrm{HCl}$ 0,1 N lalu dicukupkan sampai garis tanda dan dikocok homogen, sehingga diperoleh larutan dengan konsentrasi $500 \mu \mathrm{g} / \mathrm{ml}$. Larutan ini disebut larutan standar 1 (LS I). Dari larutan ini dipipet $5,00 \mathrm{ml}$, dimasukkan ke dalam labu ukur $50 \mathrm{ml}$, lalu diencerkan dengan $\mathrm{HCl} \mathrm{0,1} \mathrm{N}$ sampai garis tanda sehingga diperoleh konsentrasi $50 \mu \mathrm{g} / \mathrm{ml}$ (LS II).

\section{Penentuan Panjang Gelombang Serapan Maksimum}

Sejumlah 5,00 $\mathrm{ml}$ LS II dipipet, dimasukkan ke dalam labu ukur $25 \mathrm{ml}$, kemudian 
diencerkan dengan $\mathrm{HCl}$ 0,1 $\mathrm{N}$ sampai garis tanda. Lalu dikocok sampai homogen sehingga diperoleh larutan dengan konsentrasi $10 \mu \mathrm{g} / \mathrm{ml}$. Kemudian diukur serapan pada panjang gelombang 200-400 $\mathrm{nm}$.

\section{Ekstraksi Sampel}

Adsorben sebelum digunakan dilakukan pencucian (washing) dengan cara membilasnya dengan $n$-heksan, lalu dengan diklorometana, dan terakhir metanol dengan jumlah masing-masing dua kali dari volume adsorben. Kemudian keringkan dengan menggunakan vakum.

Adsorben yang telah dicuci tadi ditimbang sebanyak 4,0 g. Kemudian ditambahkan $50 \mathrm{mg}$ asam oksalat dan $50 \mathrm{mg} \mathrm{Na}_{2}$ EDTA, lalu campurkan. Sampel yang telah dihaluskan sebanyak $1,0 \quad \mathrm{~g}$ di-homogenisasi dengan campuran adsorben tadi dengan menggunakan mortir dan stamper.

Campuran sampel-adsorben dimasukkan ke dalam syringe dengan volume $10 \mathrm{ml}$ lalu tekan cartridge sampai tanda menunjukkan volume 4,5 $\mathrm{ml}$. Selanjutnya bilas dengan $10 \mathrm{ml}$ n-heksan. Setelah itu dilakukan elusi dengan menggunakan campuran etil-asetat dan asetonitril (3:1) sebanyak $25 \mathrm{ml}$. Eluat yang dihasilkan kemudian digunakan untuk analisis menggunakan spektrofotometer ultraviolet.

\section{Optimasi Prosedur Ekstraksi}

Optimasi dilakukan untuk rasio sampel dan adsorben dengan variasi $1: 2 ; 1: 3$; dan $1: 4$ pada sampel A. Penentuan rasio sampel dan adsorben yang akan digunakan untuk penentuan kadar residu tetrasiklin dalam sampel didapatkan dengan menghitung nilai perolehan kembali (\%) tetrasiklin baku yang ditambahkan pada sampel. Hasil perolehan kembali yang terbesar yang kemudian rasio sampel dan adsorbennya digunakan untuk prosedur ekstraksi kedua sampel lainnya.

\section{Penentuan Kadar Residu Tetrasiklin dalam Daging Ayam Pedaging}

Sebanyak masing-masing 4,00 $\mathrm{ml}$ larutan sampel dipipet ke dalam 5 labu ukur $25 \mathrm{ml}$, tambahkan berturut-turut 0,$00 ; 2,50 ; 3,75 ; 5,00$; dan $6,25 \mathrm{ml}$ LS II, cukupkan dengan $\mathrm{HCl} 0,1 \mathrm{~N}$ hingga garis tanda sehingga diperoleh masingmasing larutan tetrasiklin baku dengan konsentrasi 0,$0 ; 5,0 ; 7,5 ; 10,0 ;$ dan $12,5 \mu \mathrm{g} / \mathrm{ml}$. Absorbansi dari masing-masing larutan diukur pada panjang gelombang serapan maksimum kemudian dibuat grafik absorbansi versus konsentrasi standar.
Dengan mengekstrapolasikan garis pada sumbu $\mathrm{X}$ (garis memotong sumbu $\mathrm{X}$ ) atau mensubstitusikan absorbansi $(\mathrm{Y})=0$ pada persamaan regresi yang diperoleh maka akan diperoleh konsentrasi residu tetrasiklin dalam larutan sampel yang diukur $(\mathrm{Cx})$. Rumus perhitungan kadar residu tetrasiklin dalam sampel ditulis sebagai berikut.

Kadar residu tetrasiklin dalam sampel $(\mathrm{mg} / \mathrm{kg})$

$=\frac{\mathrm{Cx}(\mathrm{\mu g} / \mathrm{ml}) \mathrm{x} \text { Fakt pengenceran } \mathrm{x} \text { Vol larutan sampel }(\mathrm{ml})}{\text { Eerat penimbangan sampel }(\mathrm{g})}$

\section{Uji Validasi}

Lima parameter validasi metode yang diuji yaitu akurasi, presisi, batas deteksi, batas kuantitasi, dan linieritas. Akurasi dinyatakan dalam persen perolehan kembali (\% recovery) dengan metode penambahan standar. Presisi dinyatakan oleh simpangan baku relatif (RSD) dari serangkaian data uji perolehan kembali. Batas deteksi menunjukkan konsentrasi terendah analat dalam sampel yang masih dapat dideteksi, dan batas kuantitasi merupakan konsentrasi terendah yang masih dapat terhitung oleh instrumen. Linieritas dinyatakan dalam koefisien korelasi.

\section{HASIL}

\section{a. Pemilihan Panjang Gelombang}

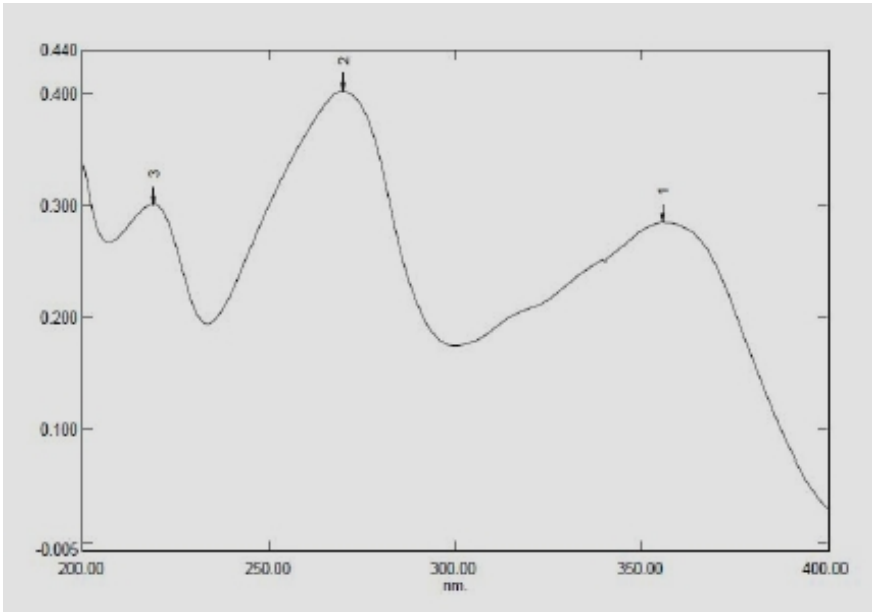

\section{Gambar 1. Kurva serapan tetrasiklin $\mathrm{HCl}$ baku pembanding Farmakope Indonesia (konsentrasi $10 \mu \mathrm{g} / \mathrm{ml}$ ) dalam pelarut $\mathrm{HCl} 0,1 \mathrm{~N}$.}

Puncak 1 pada panjang gelombang 357,5 nm dengan absorbansi 0,288; Puncak 2 pada panjang gelombang 269,4 nm dengan absorbansi 
0,409; Puncak 3 pada panjang gelombang 218,8 nm dengan absorbansi 0,290 .

Penentuan panjang gelombang maksimum dilakukan pada konsentrasi yang memberikan serapan dengan kesalahan fotometrik terkecil (absorbansi $\pm 0,4343$ ) (Moffat, 2004). Konsentrasi pengukuran dari perhitungan adalah $10 \mu \mathrm{g} / \mathrm{ml}$ dan absorbansi yang didapatkan yaitu 0,409 dengan panjang gelombang maksimum tetrasiklin hidroklorida $(\mathrm{HCl})$ standar dalam larutan $\mathrm{HCl} 0,1$ $\mathrm{N}$ adalah 269,40

\section{b. Optimasi Prosedur Ekstraksi}

Tabel 1. Hasil perolehan kembali tetrasiklin baku yang ditambahkan pada sampel A dengan variasi rasio sampel dan adsorben

\begin{tabular}{ccc}
\hline No. & $\begin{array}{c}\text { Rasio } \\
\text { sampel:adsorben }\end{array}$ & $\begin{array}{c}\text { Perolehan } \\
\text { kembali (\%) }\end{array}$ \\
\hline 1 & $1: 2$ & 42,14 \\
2 & $1: 3$ & 61,31 \\
3 & $1: 4$ & 84,40 \\
\hline
\end{tabular}

\section{c. Analisis Kuantitatif}

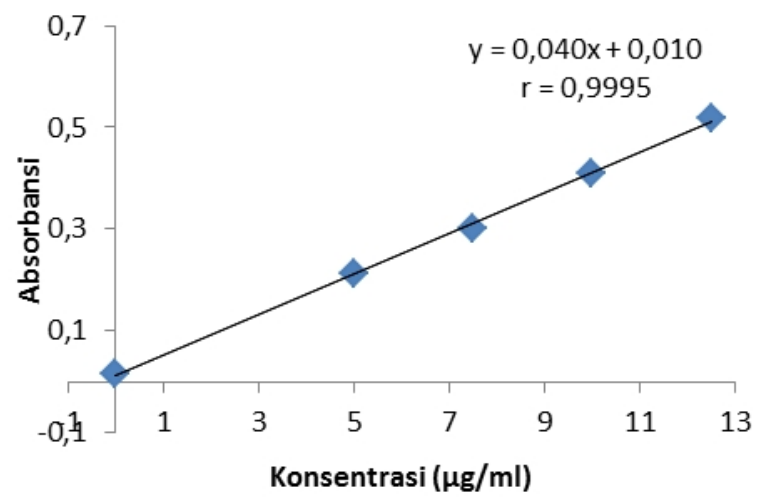

Gambar 2. Grafik penentuan konsentrasi residu tetrasiklin dalam larutan sampel A dengan metode adisi standar (ulangan I)

Tabel 2. Hasil penetapan kadar residu tetrasiklin pada sampel daging ayam pedaging

\begin{tabular}{ccc}
\hline No. & Sampel & $\begin{array}{c}\text { Kadar residu tetrasiklin } \pm \mathrm{SD} \\
(\mathrm{mg} / \mathrm{kg})\end{array}$ \\
\hline 1 & $\mathrm{~A}$ & $42,40 \pm 9,05$ \\
2 & $\mathrm{~B}$ & $61,05 \pm 3,27$ \\
3 & $\mathrm{C}$ & $44,47 \pm 3,92$ \\
\hline
\end{tabular}

\section{d. Validasi Metode}

Tabel 3. Data absorbansi hasil perolehan kembali tetrasiklin baku yang ditambahkan pada sampel A (perbandingan sampel: adsorben= 1:4)

\begin{tabular}{lllcc}
\hline & \multirow{2}{*}{ Kons. } & \multicolumn{3}{c}{ Absorbansi } \\
\cline { 3 - 5 } No. & Standar & $\begin{array}{c}\text { Ulangan } \\
\text { I }\end{array}$ & $\begin{array}{c}\text { Ulangan } \\
\text { II }\end{array}$ & $\begin{array}{c}\text { Ulangan } \\
\text { III }\end{array}$ \\
\hline 1 & 0,00 & 0,028 & 0,026 & 0,026 \\
2 & 5,00 & 0,276 & 0,281 & 0,277 \\
3 & 7,50 & 0,404 & 0,402 & 0,405 \\
4 & 10,00 & 0,545 & 0,538 & 0,538
\end{tabular}

Tabel 4. Hasil validasi metode

\begin{tabular}{cllc}
\hline No. & Parameter & \multicolumn{1}{c}{ Nilai } & Standar \\
\hline 1 & Akurasi & $84,4 \%$ & $80-110 \%$ \\
2 & Presisi & $1,36 \%$ & $<2 \%$ \\
3 & LOD & $5,16 \mu \mathrm{g} / \mathrm{ml}$ & \\
& LOQ & $5,54 \mu \mathrm{g} / \mathrm{ml}$ & \\
5 & Linieritas (r) & 0,9995 & $>0,9995$ \\
\hline
\end{tabular}

\section{PEMBAHASAN}

Ekstraksi sampel dilakukan dengan menggunakan metode Matrix Solid Phase Dispersion (MSPD). Adsorben yang digunakan yaitu ODS $\left(\mathrm{C}_{18}\right)$ yang bersifat non polar. Namun, sebelum digunakan untuk ekstraksi, adsorben dilakukan pencucian (washing) terlebih dahulu untuk memastikan tidak ada pengotor lain yang masih melekat pada adsorben. Pencucian dilakukan dengan melewatkan tiga jenis pelarut yang berbeda kepolarannya berturut-turut yaitu pelarut nonpolar (n-heksan), kemudian pelarut semipolar (diklorometana), dan terakhir pelarut polar (metanol).

MSPD telah digunakan secara luas dalam proses isolasi tetrasiklin dari matriks biologi. Pemanfaatan MSPD memiliki beberapa keuntungan diantaranya tidak memerlukan pelarut dalam jumlah besar, waktu pengerjaan relatif singkat, dan cukup selektif. Ada beberapa faktor yang mempengaruhi proses ekstraksi MSPD, salah satunya adalah rasio sampel dan adsorben. Banyaknya adsorben yang digunakan tergantung pada jenis sampel. Umumnya rasio sampel dan adsorben berkisar antara 1:1 sampai 1:4 (Kristenson et al., 2006). Oleh karena itu, pada penelitian ini dilakukan optimasi untuk rasio sampel dan adsorben 1:2; 1:3; dan 1:4.

Optimasi ekstraksi dilakukan pada salah satu faktor rasio sampel dan adsorben untuk satu 
sampel yaitu sampel A. Setelah proses ekstraksi selesai, analisis dilanjutkan dengan menggunakan spektrofotometer ultraviolet dengan teknik adisi standar. Parameter yang dihitung untuk optimasi adalah nilai perolehan kembali (recovery) dari masing-masing rasio sampel dan adsorben. Hasil perolehan kembali tetrasiklin baku yang ditambahkan pada sampel A dengan rasio sampel: adsorben $=1: 4$ yaitu $84,40 \%$ (Tabel 1$)$, jauh lebih besar dibandingkan hasil perolehan kembali dua rasio lainnya. Oleh karena itu, ekstraksi yang dilakukan untuk kedua sampel lainnya menggunakan sampel dan adsorben dengan perbandingan 1:4.

Untuk analisis kuantitatif ditentukan dengan spektrofotometer ultraviolet secara adisi standar. Metode adisi standar dipilih karena mampu meminimalkan kesalahan yang disebabkan oleh perbedaan kondisi lingkungan (matriks) sampel dan standar. Idealnya, kalibrasi standar seharusnya mendekati komposisi dari sampel yang dianalisis, tidak hanya pada konsentrasi analit tetapi juga dalam hal konsentrasi dari elemen lain yang ada dalam matriks sampel, sehingga dapat meminimalkan pengaruh dari berbagai komponen dalam sampel terhadap absorbansi yang terukur (Skoog et al., 1996). Pemanfaatan teknik adisi standar sangat membantu terutama untuk analisis senyawa yang kadarnya kecil (Ramette, 1981).

Pada Gambar 2, sumbu X merupakan konsentrasi standar yang ditambahkan sementara sumbu Y menunjukkan nilai absorbansinya. Dengan mengekstrapolasikan garis pada sumbu $\mathrm{X}$ (titik potong pada sumbu $\mathrm{X}$ ) atau mensubstitusikan nilai $\mathrm{Y}=0$ pada persamaan regresi, maka akan diperoleh konsentrasi analit yang terkandung dalam larutan sampel yang diukur (Harris, 1987).

Data kemudian diolah secara statistik untuk melihat apakah hasil perhitungan dari ketiga ulangan dapat diterima atau tidak untuk kemudian dirata-rata. Kadar residu tetrasiklin yang diperoleh dari ketiga pengulangan dihitung nilai penyimpangan bakunya (SD) yang digunakan untuk mendapatkan nilai $t_{\text {hitung. Data }}$ kadar dapat diterima apabila $t_{\text {hitung }}$ nilainya ada pada rentang $-t_{\text {tabel }}<t_{\text {hitung }}<t_{\text {tabel }}$, dimana $t_{\text {tabel }}$ dengan taraf kepercayaan $95 \%$ dan derajat kebebasan 2, sehingga diperoleh kadar residu tetrasiklin pada ketiga sampel yang diperlihatkan pada tabel 2 .

Menurut SNI 01-6366-2000, kadar residu antibiotik golongan tetrasiklin dalam daging dan susu tidak boleh melebihi $0,1 \mathrm{mg} / \mathrm{kg}$. Namun, hasil penelitian menunjukkan bahwa kadar residu tetrasiklin dalam sampel jauh lebih besar dari batas maksimum residu yang diperbolehkan.

Hal tersebut dapat terjadi apabila penggunaan tetrasiklin yang telah dimasukkan dalam ransum pakan diberikan berlebihan sehingga terjadi akumulasi residu tetrasiklin dalam tubuh ternak tersebut. Tetrasiklin juga biasa digunakan sebagai pengobatan beberapa penyakit pada ayam. Jika kemudian ayam tersebut dipotong sebelum waktu henti (withdrawal time) obat tetrasiklin, yaitu lima (5) hari untuk hewan termasuk ayam (Lastari dkk., 1987), maka masih ditemukan residu tetrasiklin dalam tubuh ayam itu. Pemakaian antibiotik yang kurang tepat kemungkinan berkaitan dengan pola pemasaran obat hewan di lapangan, yang mana peternak dapat memperoleh obat langsung dari distributor tanpa harus melalui dokter hewan (Bahri dkk., 2005).

Kandungan residu obat yang melewati batas maksimum residu (BMR) yang ditetapkan akan menyebabkan bahan makanan menjadi tidak aman untuk dikonsumsi karena dapat menimbulkan reaksi alergi, keracunan, resistensi mikroba tertentu atau mengakibatkan gangguan fisiologis pada manusia. Kasus gangguan resistensi terhadap bakteri Campylobacter yang berkaitan dengan masalah residu antibiotik telah dilaporkan di Amerika Serikat (Bahri dkk., 2005).

Validasi metode juga dilakukan terhadap prosedur yang dikerjakan pada penelitian ini. Tujuan validasi ini adalah untuk menunjukkan bahwa prosedur analitik yang digunakan telah sesuai dengan maksud yang dikehendaki. Validasi merupakan suatu persyaratan dasar untuk menjamin kualitas dan reabilitas hasil dari semua aplikasi analitik (Ermer, 2004). Parameter validasi yang diuji, meliputi akurasi, presisi, batas deteksi, batas kuantitasi, dan linieritas.

\section{Akurasi (Ketepatan)}

Akurasi prosedur ditentukan dengan menggunakan metode adisi standar (the method of standard additives). Metode ini dilakukan pada sampel A dan hasilnya dinyatakan dalam persen perolehan kembali (\% recovery). Uji perolehan kembali dilakukan untuk mengetahui kemampuan metode dan untuk mengetahui berapa persen analat yang ditambahkan dapat ditemukan. Data absorbansi hasil perolehan kembali dapat dilihat pada tabel 3. Rerata persen perolehan kembali yang didapat $84,40 \%$ telah memenuhi syarat karena rentang perolehan kembali yang masih diterima yaitu $80-110 \%$ (Botsoglou dan Fletoris, 2001). 


\section{Presisi (Ketelitian)}

Metode analisis yang teliti akan memberikan hasil pengukuran tetap pada setiap waktu dari sampel yang sama. Presisi dinyatakan sebagai standar deviasi (SD) atau standar deviasi relatif (RSD) atau koefisien variasi (CV). Presisi dikatakan baik jika memiliki nilai simpangan baku relatif kurang dari $2 \%$ dengan konsentrasi analat $0-150 \%$ (IUPAC, 2002). RSD dihitung dari data perolehan kembali. RSD yang diperoleh yaitu $1,36 \%$. Hal ini menunjukkan bahwa metode yang digunakan telah sesuai dan dapat digunakan untuk analisis residu antibiotik tetrasiklin.

\section{Batas Deteksi (LOD) dan Batas Kuantitasi (LOQ)}

Menurut IUPAC (2002), batas deteksi adalah batas konsentrasi terendah yang masih dapat dideteksi oleh instrumen. Batas deteksi dan batas kuantitasi merupakan ukuran sensitivitas dari instrumen dalam mengukur analit. Pada metode instrumen, batas deteksi ini dinyatakan sebagai konsentrasi analit pada saat rasio signalnoise 3:1 $(\mathrm{S} / \mathrm{N}=3)$ atau mengukur besarnya respon instrumen dari larutan blangko dan menghitung simpangan bakunya (Miller and Miller, 2010).

Pada hasil pengukuran absorbansi sampel A dengan menggunakan teknik adisi standar, konsentrasi standar yang memberikan absorbansi terendah yaitu $5,00 \mu \mathrm{g} / \mathrm{ml}$. Absorbansi yang dihasilkan masih memasuki rentang absorbansi yang baik yaitu 0,2-0,8 karena pada rentang tersebut hukum Lambert-Beer berlaku dan tingkat kesalahan pembacaan oleh alat adalah yang terkecil. Spektrofotometer ultraviolet tidak dapat membaca dengan baik sinyal yang diberikan dari analit dalam sampel tanpa penambahan standar (blangko), nampak pada absorbansi yang diberikan sangat rendah yaitu kurang dari 0,2 . Oleh karena itu, penentuan batas deteksi dilakukan pada konsentrasi penambahan standar $5,00 \mu \mathrm{g} / \mathrm{ml}$. Hasil perhitungan menunjukkan bahwa batas terendah analit dapat dideteksi dan dikuantitasi oleh spektrofotometer Uv adalah konsentrasi lebih dari $5 \mu \mathrm{g} / \mathrm{ml}$, sedangkan analit yang ada dalam sampel A, B, maupun $\mathrm{C}$ konsentrasinya berkisar $0,5 \mu \mathrm{g} / \mathrm{ml}$. Oleh karena itu, teknik adisi standar adalah pilihan tepat untuk menganalisis residu tetrasiklin jika ingin menggunakan spektrofotometer ultraviolet.

\section{Linieritas}

Linieritas biasanya dinyatakan dalam variansi sekitar arah garis regresi yang dihitung berdasarkan persamaan matematika menggunakan data yang diperoleh dari hasil uji analit dalam sampel dengan berbagai konsentrasi analit. Persamaan dinyatakan dengan rumus $y=$ $a x+b$, dengan a adalah kemiringan garis (slope), b adalah intersep dengan koefisien korelasi 0,9995 (Harmita, 2004).

Koefisien korelasi merupakan ketergantungan faktor sumbu $\mathrm{X}$ terhadap sumbu Y. Koefisien korelasi ini dinyatakan dengan koefisien (r) dan merentang dari -1 sampai +1 . Koefisien 1 dengan tanda + atau - menunjukkan korelasi sempurna antara dua peubah. Sebaliknya, koefien nol menunjukkan tidak adanya korelasi sama sekali (Miller and Miller, 2010).

Linieritas dilihat dari pengujian residu tetrasiklin dalam sampel A dengan metode adisi standar. Koefisien korelasi (r) dari 3 kali ulangan yaitu 0,$9995 ; 0,9997$; dan 0,9998 . Nilai ini telah memenuhi syarat metode yang baik dari segi linieritas, yaitu koefisien korelasi lebih dari 0,9995 (IUPAC, 2002).

\section{SIMPULAN}

Metode MSPD-spektrofotometri ultraviolet secara adisi standar dapat digunakan pada penetapan kadar residu tetrasiklin dalam daging ayam pedaging karena memenuhi uji validasi. Metode ini menunjukkan akurasi dan presisi yang cukup baik dengan persen perolehan kembali 84,40\%; RSD 1,36\%; LOD konsentrasi $5,16 \mu \mathrm{g} / \mathrm{ml}$; LOQ konsentrasi $5,54 \mu \mathrm{g} / \mathrm{ml}$; dan linieritas 0,9995 ; 0,9997; dan 0,9998 dari tiga kali ulangan.

Hasil penelitian menunjukkan bahwa kadar residu tetrasiklin dalam daging ayam pedaging yang diambil dari tiga pusat perbelanjaan di Bandar Lampung berturut-turut adalah 42,40 $\mathrm{mg} / \mathrm{kg} ; 61,05 \mathrm{mg} / \mathrm{kg}$; dan $44,47 \mathrm{mg} / \mathrm{kg}$. Kadar residu tetrasiklin dalam ketiga sampel yang diuji melebihi BMR menurut SNI 01-6366-2000 yaitu $0,1 \mathrm{mg} / \mathrm{kg}$.

\section{SARAN}

Berkaitan dengan tingginya kadar residu tetrasiklin dalam daging ayam pedaging disarankan kepada instansi terkait untuk memberikan informasi maupun bimbingan teknis kepada peternak ayam pedaging mengenai pentingnya petunjuk penggunaan obat hewan, 
baik yang terdapat dalam pakan komersial maupun yang digunakan untuk pengobatan.

Salah satu cara yang dapat digunakan untuk menekan bahaya potensial yang diakibatkan residu tetrasiklin pada manusia adalah dengan melakukan pemasakan. Adanya pemanasan pada suhu lebih dari $100^{\circ} \mathrm{C}$ dapat

\section{DAFTAR PUSTAKA}

Association of official analytical chemists (AOAC). 2002. Chlortetracycline, oxytetracycline, and tetracycline in edible animal tissues. Washington: AOAC Int.

Badan Standarisasi Nasional (BSN). 2000. Batas maksimal cemaran mikroba dan batas residu dalam bahan makanan asal hewan. Dalam Standar Nasional Indonesia Nomor: 01-6366-2000.

Bahri S., A. Kusumaningsih, T.B. Murdiati, A. Nurhadi, dan E. Masbulan. 2000. Analisis kebijakan keamanan pangan asal ternak (terutama ayam ras petelur dan broiler). Laporan Penelitian Pusat Penelitian dan Pengembangan Peternakan Bogor.

Bahri S., E. Masbulan, dan A. Kusumaningsih. 2005. Proses praproduksi sebagai faktor penting dalam menghasilkan produk ternak yang aman untuk manusia. Jurnal Litbang Pertanian. 24(1): 27-33.

Barker S.A. 2000. Application of matrix solidphase dispersion in food analysis. J. Chrom. A. 880: 63-68.

Botsoglou N.A. and D.J. Fletouris. 2001. Drug residues in foods: pharmacology, food safety and analysis. Marcel Dekker Inc. New York. p: 985-987, 582-586.

Brandsteterova E., P. Kubalec, L. Bovanova, P. Simko, A. Bednarikova, and L. Machackova. 1997. SPE and MSPD as pre-separation techniques for HPLC of tetracyclines in meat, milk and cheese. $Z$ Lebensm Unters Forsch A. 205: 311-315.

Cherlet M., S. Baere, and P. Backer. 2003. Quantitative analysis of oxytetracycline and its 4-epimer in calf tissues by highperformance liquid chromatography combined with positive electrospray ionization mass spectrometry. Analyst. 128: 871-878.

Christina. 2011. Penetapan kadar residu tetrasiklin dalam daging ayam pedaging secara adisi standar dengan spektrofotometri ultraviolet. Skripsi. Fakultas Farmasi USU Medan. menginaktivasi sebagian dari residu tetrasiklin yang ada.

Penelitian selanjutnya dapat mencoba menggunakan metode MSPD-spektrofotometri ultraviolet untuk menganalisis residu tetrasiklin dalam serum darah manusia yang mengkonsumsi daging ayam pedaging yang terdapat residu tetrasiklin tersebut.

Ermer J. 2004. Method validation in pharmaceutical analysis. Weinheim: Wiley-VCH Verlag GmbH \& Co. KgaA. p: 3-6.

Harmita. 2004. Petunjuk pelaksanaan validasi metode dan cara perhitungannya. Majalah Ilmu Kefarmasian. 1(3): 117-135.

Harris, D.C. 1987. Quantitative chemical analysis. $2^{\text {nd }}$ Ed. W.H. Freeman and Company. New York. p: 585-586.

Kristenson E.M., L. Ramos, and U. Brinkman. 2006. Recent advances in matrix solidphase dispersion. Trends in Anal. Chem. 25(2): 96-111.

Lastari P., E. H. Kristyanto, N.I. Pracoyo. 1987. Analisa residu tetrasiklin dalam ayam broiler. Cermin Dunia Kedokteran. 46: 2830.

Miller J.N. and J.C. Miller. 2010. Statistics and chemometrics for analytical chemistry for analytical chemistry. Sixth Edition. Ashford Colour Press. UK.

Moffat A.C. 2004. Clarke's isolation and identification of drugs. 3rd Ed. The Pharmaceutical Press. London.

Munson J.W. 1991. Analisis farmasi metode modern. Penerjemah: Parwa Harjana B. Airlangga University Press. Surabaya. hlm: 334.

Muriurki F.K., W.O. Ogara, F.M. Njeruh, and E.S. Nitema. 2001. Tetracycline residue levels in cattle meat from Nairobi salughter house in Kenya. J. Vet. Sci. 2(2): 97-101.

Ramette R.W. 1981. Chemical Equilibrium and Analysis. Addison-Wesley Publishing Company. London. p: 74.

Skoog D.A., D.M. West, and F.J. Holler. 1996. Fundamental of analytical chemistry. $7^{\text {th }}$ Ed. Saunders College Publishing. New York. p: 572-574.

Suryani D. 2009. Validasi metode analisis residu antibiotik tetrasiklin dalam daging ayam pedaging secara kromatografi cair kinerja 
tinggi. Skripsi. Departemen Kimia FMIPA dalam produk peternakan (susu dan daging). IPB Bogor.

Yuningsih. 2004. Keberadaan residu antibiotika Dalam: Lokakarya Nasional Keamanan Pangan Produk Peternakan. Balai Penelitian Veteriner. Bogor. hlm: 48-55. 